\title{
Commercial Arbitration in California
}

$\mathrm{O}$ N JANUARY 19, 1927, the Honorable Leland Jacobson, chairman of the Judiciary Committee in the Assembly, presented Bill Number 460 to the California Legislature. This measure is designed to amend the existing law on arbitration in the State of California. Its provisions can be summarized very briefly as follows:

A provision in a written contract to settle by arbitration a controversy arising out of the contract is made valid, enforceable and irrevocable, save upon such grounds as exist at law or in equity for the revocation of any contract.

There are two methods for enforcing the arbitration agreement. First, any suit commenced upon an issue referable to arbitration may be stayed until arbitration is had, unless the applicant for the stay is in default with the arbitration. Second, the court may order the arbitration to proceed in accordance with the agreement, appointing an arbitrator itself, if appointment under the agreement cannot be had.

The proceeding is commenced by service of notice of an application for stay or order, as though it were a summons in an action. Five days' notice is required. If the making of the agreement is in issue, that issue alone is summarily tried, either by jury, or by court if no jury trial is demanded. If there is no such issue, the application is heard and determined as though it were a motion before the court. The arbitrators are given power to secure the attendance of witnesses and to bring before them such documents as are necessary.

The grounds for vacating, modifying or correcting an award are limited and the motion must be made within three months from the award. If award was procured by corruption, fraud or undue means, if there was evident partiality upon the part of an arbitrator, if the arbitrators were guilty of misconduct or if they exceeded their powers, then the award may be vacated. If there was a mistake on the face of the award, or if the award was imperfect in form, then it may be modified. Any party to the arbitration may apply for an order confirming an award, and the successful party must file with the clerk of the court certain papers specified in the bill, those upon which the order of confirmation rests. The judgment so entered is subject to the same provisions of law as any other judgment, whether as to enforcement, appeal therefrom, or in any other respect.

This measure, if passed, will change the doctrine of the common 
law as adopted in California and codified in Sections 1281 et seq. of the Code of Civil Procedure and Section 3390 of the Civil Code and the exristing form of statutory arbitration therein set forth. ${ }^{1}$ In California at the present time an executory agreement to arbitrate is unenforceable. It cannot be pleaded in bar of an action, and will not support a motion to stay proceedings. ${ }^{2}$ It will support an action for damages for its breach, but damages are limited to the amount spent in preparing for the arbitration. ${ }^{3}$ Such an agreement will not be specifically enforced. ${ }^{4}$ When the agreement has been executed, however, the award is final and conclusive, and upon it suit may be brought. $^{5}$

Several reasons have been advanced for the refusal of courts to compel men to abide by their arbitration agreements. ${ }^{b}$ The earliest view taken was that arbitrators were agents; hence followed the doctrine of revocability. The agency theory was soon discarded, and the reason then advanced has remained to plague modern judges. That is that such agreements are against public policy since they tend to oust the legally constituted courts of jurisdiction. Judges have lampooned this explanation as a relic of the days when the King's Courts sought to extend their jurisdiction because the amount of the judges' fees was directly dependent upon the volume of business transacted." In the words of Judge Hough, "It is surely a singular view of juridical sanctity which reasons that, because the Legislature has made a court, therefore everybody must go to the court."

1 Cal. Code Civ. Proc. $\$ \S 1281-1290$. The submission must be in writing and any controversy which might be the subject of a civil action between the parties, except a question of title to real property in fee or for life, may be submitted. The arbitrators are given power to set the time and place of hearings, to administer oaths and to make an award on the evidence. The arbitrators must be sworn and their award must be in writing. If so stipulated, the submission may be entered as an order of the superior court. In such a case it must be filed with the county clerk, who must enter in his register of acticins a note of the submission with the names of the parties, the name of the arbitrators, the date of the submission when filed and the time limited by the submission, if any, within which the award must be made. This submission cannot be revoked without the consent of both parties. If the submission is not made an order of the court, it may be revoked at any time before the award is made. The award may be vacated, modified or corrected on motion in certain cases. The decision upon the motion is subject to appeal, but the judgment entered before a motion made cannot be subject to appeal.

2 Blodgett Co. v. Bebe Co. (1923) 190 Cal. 665, 214 Pac. 38; (1923) 12 California Law Review, 32.

${ }^{3}$ Cal. Code Civ. Proc. $\$ 1290$.

4 Cal. Civ. Code, \$3390.

5 Digan v. Phillips (1926) 49 Cal. App. Dec. 768, 246 Pac. 566.

6 Cohen, Commercial Arbitration and the Law.

7 See Lord Campbell's remarks in Scott v. Avery (1855) 25 L. J. (Exch.) 308, 312, 10 Eng. Rep. R. 1121.

8 U. S. Asphalt Co. v. Trinidad Co. (1915) 222 F. 1006. 
Again and again one comes upon the statement that agreements to arbitrate future disputes are against public policy." "That two merchants of full age and mental competency should not be permitted by the laws of their country to stipulate for the adjustment and settlement of controversies between them exclusively by the arbitration of a fellow merchant would seem incredible to a layman. . . . Such at one time was the law of England . . . as well as that of most of the states of the Union. There could be no better example of the vitality and persistence of a false doctrine when it once lodged in the body of our common law than the history of the common law of the invalidity of arbitration agreements." 10 The rule has been called an anachronistic survival and the rule of stare decisis blamed for its existence. ${ }^{11}$

Public policy is a broad phrase and often loosely used. As applied to arbitration agreements the statements are mere dicta since no investigation of the use of arbitration in California had ever been made. Whether public policy should support arbitration agreements or discourage them would seem to depend upon the effect had on the community. If the enforcement of arbitration agreements would benefit the community then public policy would favor such contracts.

On behalf of the American Arbitration Association of New York the writer undertook an investigation of the use of arbitration by trade and commercial organizations in California. The results obtained may be of some aid in ascertaining what the proper public policy should be.

What Is Arbitration? Arbitration is the voluntary submission of a controversy, by the parties interested, to one or more unofficial persons chosen by them, directly or indirectly, to investigate and determine the matter. ${ }^{12}$ It is not to be confused with compromise,

- Blodgett Co. v. Bebe Co., supra, n. 2.

10 Harlan Fiske Stone, now Associate Justice of the United States Supreme Court, in a paper read at the 1923 meeting of the Academy of Political Science in the City of New York. Mr. Stone was present to point to the limitations of arbitration in various situations in which only the courts can afford needed relief.

11 (1923) 12 California Law Review, 32; (1924) 12 California Law Review, 497.

i2 The antiquity of arbitration as a procedure for the settlement of commercial disputes is evidenced by the references in the Year Books of Edward II to the common law action of account, where the court appointed an auditor to pass on the respective merits of mutual claims between the parties and to determine the balance due. The "dusty-foot" or Pie-poudre court was a tribunal of laymen which functioned at fairs and markets in medieval England in order to summarily dispose of controversies between buyers and sellers. The history of arbitration has been traced from the Hebraic Beth Din of Biblical times down to the modern Handelsgerichte of Germany, 
mediation, or other words descriptive of friendly efforts to arrange differences by the suggestion of mutual concessions between the parties. It is a method for the determination of rights and the enforcement of remedies, by which a party aggrieved may ascertain and cibtain all that he is entitled to from his opponent, without instituting, an action in the courts of law. Arbitration differs from the systern of commercial tribunals in vogue on the continent. The latter, forming a part of the system of courts, are set up and maintained by governmental agencies and have a fixed jurisdiction. ${ }^{13}$ In California the arbitration tribunals are chosen entirely without official assistance, their jurisdiction rests entirely upon the consent of the parties who apply to them for relief and the aid of the law is negligible.

Two main types of arbitral tribunal were found. One is composed of arbitrators selected by or for the disputants for the settlement of a particular controversy. The powers of such a board exteni only to the adjudication of the dispute submitted to them. The cther is made up of arbitrators chosen by a trade or commercial organization who exercise their functions over a fixed period, although their relation to any particular arbitration is like that of arbitrators chosen ad hoc. The arbitrators are selected because of their expert knowledge of the trade, its customs, the value of the goods and the general conditions existing in the business out of which the dispute arises. They may he men active in the same or a related business, or retired from active participation therein. In San Francisco the frequency with which certain men of known ability and fairness are called upon to act shows the tendency towards the building up of a class of arbitrators, the existence of which tends to create a tradition among businessmen generally favorable to the settlement of disputes by this extra-legal method.

Use of Arbitration in California. We have seen the unfavorable attitucle of the law in California towards arbitration agreements. It is not surprising to find that the arbitrations under the existing statute ${ }^{14}$ are so few that the law is spoken of as a dead letter. It is remarkable, however, that a great number of trade associations provide some means for the arbitration of disputes that arise among

in a paper read by Mr. $\mathrm{H}$. Bentwich at the Annual Provincial Meeting of the Incorporated Law Society at Manchester, October 11, 1893, reprinted in 95 Law Times, 524.

13 Samuel Rosenbaum, A Report on Commercial Arbitration in England, Bulletin XII, American Judicature Society. 14 Cal. Code Civ. Proc. \$\$ 1281-1290. 
members or between members and others, and sometimes between non-members engaged in similar lines of business. Although the parties have the legal privilege to revoke their submission, in most cases the disciplinary powers of the association are enough to compel adherence to the arbitration procedure.

The investigation brought to light over thirty associations in California which practice arbitration as part of their functions in furthering the interests of the members and the trade. These associations have memberships running into the thousands and almost all the key-industries in the state which are organized into trade organizations either use arbitration or favor its principle. The survey indicated that business opimion and practice solidly favored the settlement of commercial disputes by arbitration and in no case did any businessman or organization voice an objection to its use as an integral element in the business process. In the production, sale and distribution of staples and raw products, in the building trade, motion picture industry, real estate and many other branches of industry and business, arbitration has come to be recognized as an important element in the contractual relation. ${ }^{15}$

Reasons for Arbitrating. The evident predilection of the world of business for the domestic tribunal of arbitration rather than the court of law is explicable on several grounds. Business men claim that commercial disputes differ essentially from others, aside from their technical nature. The settlement of a given controversy is not the ultimate desire of the parties, who wish to conserve the relationship existing between them as units in our economic structure. John Doe, packer, wishes to keep Richard Roe, wholesaler, as a customer. It is in the interest of both parties that their position in the market remain fixed as buyer and seller. The law ignores this desire in its formal tribunals. The courts seek to administer exact justice, but the procedure is one of contention rather than inquisition. The parties seek to get at the truth by assuming hostile positions and their artificial enmity is often enhanced by the tactics of counsel. Thus a trial at law tends to cause irritation and bad feeling between the parties which leads to a disruption of a business relationship which society now regards as of the utmost importance. Changed methods of production and distribution have emphasized the essential interdependence of the economic units of society, and the conservation of permanent business connections is a cardinal aim of the business community. "Arbitration is seen as a constructive social function

15 Dunn and Dimond, Commercial Arbitration. 
-weaving into the fabric of commercial life to strengthen rather than sever its threads."16

Anlother factor favoring arbitration is the congestion of the courts in the populous centers of California. Business people dislike "going to law" because it is too slow, too expensive and too much of a gamble. In Los Angeles County the number of civil cases pending in the Superior Court at the beginning of 1927 was 25,000. The court disposes of 11,000 cases annually and the claim is made that this is disposing of more cases per year per court than is done in any other similar jurisdiction in the United States. Yet more actions are filed annually than can possibly be handled by the court despite the fact that it has twenty-eight regular and seven special departments. The percentage of business disputes in the cases now pending is about fifty per cent..t7

In the City and County of San Francisco the number of civil action:s now pending in the Superior Court is 47,000 . The court last year disposed of about 9,000 cases, and about 12,000 new ones were filed in the same period. Some eight or nine other counties have so much business that extra departments are needed to take care of it.

The first attempt made to cope with this situation was the creation of the Judicial Council ${ }^{18}$ which is empowered to transfer judges to assist courts with congested calendars. The effects of this measure are yet to be seen, but it is hoped that the condition may be ameliorated. The effects of such delay are fittingly described by Joseph Wheless:

"In these years of law's delays rights suffer irreparable wrong; wrongs go unrighted; parties and witnesses die, scatter and disappear; evidence is lost or destroyed; memories fail and testimony loses its distinct value; frauds and prejudices evolve and ase matured; insolvencies and bankruptcies intervene, so that when the tardy day of judicial trial drags the often seriously weakened case to the bar of justice, justice ofttimes cannot be hald . . ."19

Those who arbitrate set forth as one of the foremost advantages of the procedure the expert knowledge which the arbitrator brings

${ }^{16}$ Herbert Harley, Introduction to Bulletin XII, Commercial Arbitration, of the American Judicature Society.

It Figures were obtained from the responsible officials in the course of the survey.

18 Senate Constitutional Amendment 15, passed at the election in November, 1926.

19 Joseph Wheless, Arbitration as a Judicial Process of Law (1924) 30 West Virginia Law Quarterly, 209. 
to the determination of the cases submitted. Most of the questions are primarily those of fact, dealing with quality, quantity, condition, value, and trade customs. It is obvious that the truth is more easily ascertainable by a specialist of his own knowledge than by a jury at second hand.

Another great advantage of arbitration over the law courts is in the matter of procedure. It is flexible and permits adaptation to the convenience of the parties and the nature of the controversy. In the presentation of evidence, the rules which bind our courts in a Gordian knot, and are a token of the contempt of the law for the intelligence of juries, present no hindrance. The arbitrators may admit any evidence and may believe what they please. The archaic "hearsay" and "best evidence" rules are most objectionable to business men since they prevent the introduction of books and records which are necessary in modern bookkeeping and accounting practice. ${ }^{20}$ The avoidance of publicity is a great boon to many industries. Litigation may lose many customers througl unwelcome notoriety. Most business people resent the publication of their names in connection with law suits, especially when they are defendants. The loss of trade secrets deters more than one wronged individual from prosecuting a claim in the courts of law. They find it cheaper to swallow injustice than to seek the remedy of law.21

The Bean Dealers' Association of California, which has pioneered in the use of arbitration, has found that the presence of an arbitration clause in a contract is potent in preventing disputes; the parties know that any controversy arising will be settled quickly and efficiently, which prevents parties from seeking trouble for the sake of delay. However, many disputes which would never have been litigated but would have been marked up to profit and loss, now are arbitrated. Thus, arbitration removes an objectionable type of case and brings up those with real differences of opinion which cannot be settled by conciliation, and gives parties an opportunity to claim rights in small matters as well as large. The result is a healthier business relation in which there is less cause for bearing grudges or for grumbling because of injustice for which there is no redress.

The advocates of arbitration claim that it is cheaper than litigation. The records of arbitration of the San Francisco Chamber of Commerce show cases in which large sums were involved and in

20 Wesley A. Sturges, Commercial Arbitration or Court Application of Common Law Rules of Marketing (1924) 34 Yale Law Journal, 480.

21 Moses H. Grossman. Speeding up Justice Through Arbitration (1923) 5 Illinois Law Quarterly, 135. 
which the charges were surprisingly low. There is no doubt that small matters can be put through arbitration less expensively than through litigation. However, the results in England lead the investigator to conclude that the average arbitration is no cheaper than the average law suit in actual expenditure. But if one reckons the speed with which a case is settled and the satisfaction which comes from an intelligent award, combined with the otber advantages of arbitration, then it is more economical. ${ }^{22}$

Arbitration Practice in California. The Stock Exchanges of San Francisco and Los Angeles practice arbitration for the settlement of disputes between members and also provide a means for the settlement of disputes with outsiders. The practice of arbitration among memlers of such an exchange rests completely upon the power of the exrchange to discipline its members and since it is a close corporation they must conform to the rules or be cut off completely. In such cases the arbitrations take place because the rules make them compulsory rather than because of any individual agreements.

In the trade associations the primary purpose is co-operation for the benefit of the trade. Several ways are used to attain this end by minirnizing the opportunities for litigation. The Foreign Trade Association of the Pacific Coast publishes a booklet of rules defining trade terms and customs. Uniform contract forms are provided by many associations for the use of members. These seek to cover any contingency which may arise and to give members every possible protection without placing obstacles in the way of business. Almost invariably these contract forms contain an arbitration clause. The following clause from the Uniform California Bean Contract is an illustration:

"Arbitration: Any dispute arising under this contract shall be settled by arbitration. If such arbitration involves a question of quality it shall be held before the Arbitration Board of the California Bean Dealers' Association at San Francisco or Los Angeles, seller's option. If such arbitration does not involve a question of quality, it shall be held either in San Francisco, :Los Angeles, New York, Chicago, St. Louis or New Orleans. The particular one of such cities in which arbitration is to be held shall in the absence of other agreement by the parties be that one which is nearest the destination of the shipment.

"Arbitration in San Francisco or Los Angeles shall be held before the Arbitration Board of the California Bean Dealers' Association in accordance with its rules, in New York, Chicago, or St. Louis, before the Dried Fruit Association of such city in

2:: Samuel Rosenbaum, op cit., supra, n. 13. 
accordance with its rules, and in New Orleans, before the committee of the New Orleans Board of Trade, Ltd., in accordance with its rules.

"If the decision is in favor of the seller, the invoice, if unpaid, shall become due and payable at once. If the decision is against the seller, the arbitrators shall determine and fix the amount of allowance to be deducted from the invoice, which allowance, if the draft has been paid, shall be refunded immediately to buyer; provided, that if the arbitrators find a variation in excess of one per cent of damaged beans and for foreign matter from the standard for the goods sold, the buyer shall be entitled to elect within such time as the arbitrators may specify either to reject outright, or to accept the allowance fixed by the arbitrators. The arbitrators shall be entitled to assess costs of arbitration, and the decision shall be final and binding on both parties, who hereby agree to comply therewith. Failure of seller to ship, or of buyer to accept, shall be considered a dispute to be settled by arbitration.

"Either party to an arbitration before the Arbitration Board of the California Bean Dealers' Association may appeal from an award involving any questions other than quality, such appeal being to the board of directors of the California Bean Dealers' Association (Northern or Southern Division), under the rules of said association.

"Samples for arbitration shall be drawn while shipment remains intact from not less than five per cent of the shipment jointly by representatives of both buyer and seller, or by a disinterested party agreed upon by both parties.

"Buyer shall have no right of claim nor be entitled to arbitration for any cause unless claim is made or arbitration demanded by telegram within three full business days after arrival of goods."

In the state of the law of arbitration in California it is pertinent to inquire how such arbitration agreements are enforced in this state. The answer given by all the associations is "trade organization action." The disciplinary power over members who refuse to arbitrate is ready to be exercised, and in the records of over 3,000 arbitrations only twenty repudiations have been found. Fine, suspension, or expulsion is a severe penalty, and the members find it advisable to submit. Furthermore there is a general opinion in the business community which has awakened to the benefits of arbitration against the breach of such agreements, and experience has shown a higher standard of business ethics since the introduction of arbitration. Such enforcement apphies to associations whose membership is made up of persons concerned with most of the stages in the process of fabricating and distributing a given product. The members deal 
with one another and disagreements are confined to parties within the immediate control of the organization.

Most associations comprise persons who bear a like relation to a given market, as buyers or sellers. Transactions are mainly with persons not members, and disputes which arise concern parties who are not within the jurisdiction of the association. Such organizations are confronted with the problem of inducing non-members to submit their disputes to the judgment of a tribunal which functions under the auspices of a group representing their opponents in interest. The success of many organizations in this endeavor points to high standards of business ethics.

Another effort to remedy the situation produced by the ineffectiveness of the arbitration law where one of the parties is not a member of the association, has been the creation of a joint arbitral procedure. The contracting parties may each belong to an association, and the furtherance of arbitration may be secured by the co-operation of such related associations. In California the Distributors' and the Exhibitors' Associations maintain a Joint Arbitration Board for the Motion Picture Industry, which functions to the satisfaction of the members.

Procedure in Arbitration. It is the common experience of business men that factual differences in the course of dealings outnumber difierences as to law many times over. The great source of dispute in every business dealing with the purchase, sale, manufacture or distribution of some form of material article, is the quality, condition or value of the article at the time of delivery. Other fields of controversy are also primarily questions of fact although sometimes having to do with the simpler questions of law such as warranties, passage of title and so on. The ideal tribunal for such cases is one possessing direct knowledge of the values, technical terns, customs and business conditions prevailing in any trade.

The tribunals set up by the trade associations aim to combine such knowledge possessed by their members with the judicial quality which responsibility engenders. ${ }^{23}$ These boards vary in their structure with each association. Such an association as the San Francisco Chamber of Commerce, which has a membership covering many varied industries, maintains a permanent arbitration board representing as far as practicable the various branches of business transacted in the Chamber. The board of directors are also empowered to elect alternate members of the Arbitration Committee, 
who shall be members of the Chamber having a practical knowledge of the quality, grade, or value of any special commodity.

In a great many arbitrations the parties themselves appoint their arbitrators. Experts in the use of arbitration prefer the permanent impartial tribunal, although if the parties desire to select their own tribunal, a sole arbitrator is better. When each side appoints its own arbitrator they tend to become advocates, instead of impartial judges, which leaves the decision to the third arbitrator who was not selected by the parties.

The manner of presenting the case varies with each association. Some require the presentation of written statements. Others hold hearings at which the parties are present to testify. Still others combine the written presentation with oral hearings. The Canners' League of California has an interesting variation known as the "blind" arbitration. This is also used by several associations. The case is submitted to the arbitrators in writing and all identification marks are removed. The decision is made without revealing the identity of the parties to the arbitrators.

Certain associations permit an appeal, but once the award is final the matter is considered settled. The experience of trade has been that such awards are immediately complied with, and in very few cases has a suit at law on the judgment been found necessary.

Conclusion. In determining the public policy on arbitration for the state of California it is fitting to see what other states have done.

New York in 1920 passed an arbitration law similar to the measure now pending before the California Legislature, ${ }^{24}$ and in 1926 the Federal Arbitration Act became effective. ${ }^{25}$ The New York statute

24 N. Y. Laws 1920 , c. 275 , p. 803 ; other states have amended their arbitration laws; N. J. Laws 1923, c. 134, p. 291 ; Mass. Gen. Laws, c. 251 (as amended by acts 1925 , c. 294) ; Ore. Laws 1925, c. 186, p. 279.

${ }^{25}$ Act of Congress of Feb. 12, 1925, c. 213,43 U. S. Stats. at I. 883. This statute makes written arbitration agreements "valid, enforceable and irrewocable" within the limits of federal jurisdiction. Query, whether the federal jurisdiction extends to the remedy on a contract having to do with interstate commerce? An interesting situation is presented when the transaction is intra-state commerce but suit on the contract containing an arbitration clause is brought in the federal court because of diversity of citizenship. Lappe v. Wilcox (1926) $14 \mathrm{~F}$. (2d) 861 , dealt with a case where the contract had been executed in New York and the agreement to arbitrate the dispute had also been made there. The defendant moved to stay proceedings until arbitration had been had. The District Court denied the motion. The New York statute on arbitration agreements was held to be remedial and therefore inapplicable in the federal courts. In such a case the arbitration agreement did not come within the terms of the Federal Arbitration Law since the contract evidenced a transaction of intra-state commerce. Thus we see that the agreement to arbitrate remains unenforceable despite the change in policy regarding such contracts. The remedy for such a situation would seem to lie in amending the Judicial Code to make all arbitration agreements, if valid where made, enforceable in the federal courts. 
which is similar to Assembly Bill Number 460 has been upheld as constitutional by the New York Court of Appeals in an opinion wr:tten by Judge Cardozo. ${ }^{26}$ The right of jury trial is one which may be waived by the parties. Nor is the constitutional jurisdiction of the court abridged when the legislature makes enforceable agreements to arbitrate. "We think there is no departure from constitutional restrictions in this legislative declaration of the public policy of the state." 27

What are the objections to such an amendment of the arbitration lawr? The only objections voiced in the course of this investigation arcse from the legal profession. ${ }^{28}$ The most commonly offered argument is that such a statute would be available as an instrument of oppression by powerful corporations which might dictate terms to smaller individuals and concerns and compel arbitration before biased boards of arbitrators. It would seem obvious that the protection of the courts is provided for relief against oppressive contracts and should an arbitration tribunal be partial or unfair, the measure permits the court to correct or vacate the award. It has been the prectical experience of business people in states which have such a law that the smaller concerns are benefitted the most by arbitration. The large concerns can afford to litigate, to pay expensive counsel, and to carry the overhead involved in the tying up of assets in court actions.

In some cases the objection of the profession has been based on the fear of competition. Does arbitration lessen the practice of the lawryers? The development of arbitration in England may be enlightening. ${ }^{29}$ Far from limiting the lawyers' business it has opened up a lucrative field for those men who were keen enough to give business what it wanted, speed and efficiency. Lawyers there take an active part in the presentation of arbitrations, and certain IKings' Counsel have become noted as arbitrators in special lines. Many cases which would never be litigated are arbitrated. Cases are cleaned up in much less time and the lawyer's net profit increases although individual returns may decrease. In any event, the business world wants to arbitrate and it does arbitrate, and it behooves the lawyer to get into step with business policy.

The investigation of arbitration in California has shown the

\footnotetext{
- 26 Berkovitz v. Arbib (1921) 230 N. Y. 261, 130 N. E. 288.

27 Berkovitz v. Arbib, supra, n. 26.

28 Proceedings of the 15th Annual Meeting California Bar Association, 1924, p. 70; Proceedings of the 16th Convention of the California Bar Association, 1925, p. 93.

29 Samuel Rosenbaum, op. cit., supra, n. 13.
} 
tremendous scope of this procedure despite the unfavorable state of the law. The passing of the present bill to amend the law should make the benefits of arbitration available to many more concerns and businessmen. A word of warning is apropos. Arbitration ought not to be regarded as a panacea for the ills which trouble the administration of justice. It is a remedy eminently fitted for most of the disputes arising out of commercial transactions. It is certainly not a proper remedy for questions with which the arbitrators have no experience and which are better left to the regularly organized courts for settlement.

It should be the province of business men and lawyers to see that no abuse of the arbitration agreement is permitted. Agreements to arbitrate future disputes should be restricted to those cases in which there is a body of established customs and well settled standards of quality and conduct, with which both the arbitrators and the disputants are familiar and according to which it is just to settle the dispute. Arbitration agreements, if used intelligently, should benefit the wider community as they have benefitted those trades which have pioneered in its practice.*

Martin Gang.

Berkeley, California.

* [Assembly Bill No. 400, amending Code of Civil Procedure, relative to arbitration and awards, was approved by the Governor on April 27, 1927, chaptered as Chapter 225, and filed with the Secretary of State.-ED.] 